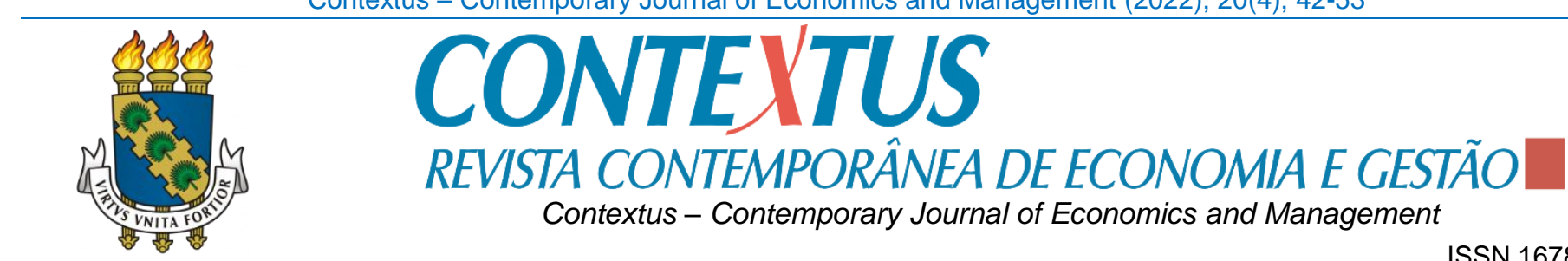

FEDERAL UNIVERSITY

ISSN 1678-2089

of CEARÁ

www.periodicos.ufc.br/contextus

ISSNe 2178-9258

\title{
Phenomenography as a research method for Management education
}

\section{Fenomenografia como método de pesquisa para a educação em Administração \\ Fenomenografía como método de investigación para la educación en Gestión}

\section{Gabriela Tavares dos Santos}

https://orcid.org/0000-0002-6832-8681 (D) Professor at the Federal University of Paraíba (UFPB)

$\mathrm{PhD}$ in Administration from Federal University of Paraíba (UFPB)

gtds@academico.ufpb.br

\section{Anielson Barbosa da Silva}

https://orcid.org/0000-0002-6549-9733 (D) Professor at Federal University of Paraíba (UFPB)

$\mathrm{PhD}$ in Production Engineering from Federal University of Santa Catarina (UFSC)

abs@academico.ufpb.br

https://doi.org/10.19094/contextus.2022.71414 do

\section{ABSTRACT}

This methodological essay characterises phenomenography as a research method to broaden the understanding of the phenomenon of management education in Brazil. The historical evolution, epistemological positioning, and basic elements of the method are presented first, followed by a description of the phenomenographic research process, with an emphasis on the scenario, and the procedures for data collection and analysis to identify the convergent perceptions or conceptions. For management education, the results of studies underpinned by phenomenography may help agents involved in the teachinglearning process understand how students and professors experience phenomena and aid not only in how curricula are structured but also in the planning process and the teaching in the environment where students learn.

Keywords: phenomenography; research method; management education; experience; teaching.

\section{RESUMO}

Este ensaio metodológico caracteriza a fenomenografia como método de pesquisa para ampliar a compreensão do fenômeno da educação em administração no Brasil. A evolução histórica, o posicionamento epistemológico e os elementos básicos do método são apresentados, além de uma descrição do processo de pesquisa fenomenográfica, com ênfase no cenário, e os procedimentos de coleta e análise de dados para identificar as percepções ou concepções convergentes. Para o ensino de Administração, os resultados dos estudos embasados na fenomenografia podem auxiliar os agentes envolvidos no processo de ensino-aprendizagem a compreender como alunos e professores vivenciam os fenômenos e auxiliar não só na forma como os currículos são estruturados, mas também no processo de planejamento e ensino no ambiente onde os alunos aprendem.

Palavras-chave: fenomenografia; método de pesquisa; educação em administração; experiência; ensino.

\section{RESUMEN}

Este ensayo metodológico caracteriza la fenomenografía como un método de investigación para ampliar la comprensión del fenómeno de la educación gerencial en Brasil. Se presenta la evolución histórica, el posicionamiento epistemológico y los elementos básicos del método, seguido de una descripción del proceso de investigación fenomenográfica, con énfasis en el escenario, y procedimientos de recolección y análisis de datos para identificar percepciones o concepciones convergentes. Para la enseñanza de la Gestión, los resultados de los estudios basados en la fenomenografía pueden ayudar a los agentes involucrados en el proceso de enseñanza-aprendizaje no solo en la forma en que se estructuran los currículos, sino también en el proceso de planificación y enseñanza en el entorno donde los estudiantes aprenden.

Palabras clave: fenomenografía; método de investigación; educación gerencial; experiencia; enseñanza.

\section{Article Information}

Uploaded on $13 / 07 / 2021$

Final version on $03 / 11 / 202$

Accepted on $05 / 11 / 2021$

Published online on 22/02/2022

Interinstitutional Scientific Committee Editor-in-chief: Diego de Queiroz Machado

Evaluation by the double blind review system (SEER / OJS - version 3)
How to cite this article:

Santos, G.T., \& Silva, A.B. (2022). Phenomenography as a research method for Management education. Contextus - Contemporary Journal of Economics and Management, 20(4), 42-53. https://doi.org/10.19094/contextus.2022.71414 


\section{INTRODUCTION}

There are different research strategies in the methodological field that can be used to understand management education, essentially revolving around the approach to which they are linked. In the quantitative approach, the social world is composed of concrete empirical elements with identifiable social relations and understood through measures that emphasise statistical techniques (Burrel \& Morgan, 2017), a reasoning strongly based on linear attributes and measures (Stake, 2016). The qualitative approach involves attempts to understand how reality is socially constructed to reveal the meanings of the subjects' experiences, using collection and analysis techniques that aim to understand the 'what', 'how' and 'why' of phenomena (Merriam \&Tisdell, 2015).

These two approaches used by researchers to understand reality do not need to be treated as incommensurable but, rather, as complementary, since all scientific knowledge "is a mixture of quantitative and qualitative thinking" (Stake, 2016, p. 23). The difference between the quantitative and qualitative lies in their nature (Minayo, Deslandes \& Gomes, 2011); they carry two different ways of understanding reality, indicating that the quantitative-qualitative dichotomy should not exist (Silva \& Roman, 2010).

However, every research approach is underpinned by ontological and epistemological assumptions that lead the researcher to see reality in a different way and supports the delineation of methodological procedures for answering a research question.

In the field of education, the 1970s witnessed the emergence of a research method named phenomenography, which has been used in higher education (Cousin, 2009) and focuses on the conception of teaching or a student-centred understanding, as opposed to more traditional approaches that adopt professor-centred methodologies, techniques and skills (Postareff, LindblomYlänne \& Nevgi, 2008). Phenomenography does not dismiss professor-centred studies, since they can be understood as complementary, but rather proposes a broader gaze to understand and describe the impact of the learning process on students through their experiences (Marton, 1981).

A comparative analysis between phenomenography and other research strategies helps explain their specificities. In phenomenography, there is no need for a special case, as in the case study, nor an agent of a group or community, as in ethnography, nor a pursuit of solutions and interferences, as in action research, nor construction of a theory, as in grounded theory. Given the etymological similarities between phenomenography and phenomenology, some may believe that their ontological and epistemological assumptions are similar. The only similarity between the two research strategies is that both seek to study the world as perceived by a group of people in a defined context. Whereas phenomenology searches for the essence of the phenomenon under study, phenomenography attempts to identify the variation in perception based on experience (Marton, 1981). Phenomenology has a history of more than a century, whereas phenomenography has a more recent history, as it was developed in the 1970s (Pherali, 2011).

In phenomenography, experience is understood through its reference and structure. These elements signify the 'what' (referential aspect) and 'how' (structure) of experience. The structural aspect of experience is divided into external (how we understand the experience using the external context) and internal (how we understand the experience itself). These aspects are interlinked and interdependent, and this approach is thus non-dualistic, since it understands that it is impossible to separate subject (people) and object (phenomenon) when describing a phenomenon (Marton, 1981).

Despite its advances, phenomenography is not a popular research method in the academic field, as explained in previous researches (Åkerlind, Mckenzie \& Lupton, 2014; Åkerlind, 2008; Çekmez, Yildiz \& Bütüner, 2012; Santos, Leal, Alperstedt \& Feuerschütte, 2018; Zhao, Mcconnell \& Jiang, 2009). A systematic review of empirical studies using phenomenography, carried out in Brazil by Santos et al. (2018), showed that a number of only 26 works - four doctoral theses, eleven dissertations, and eleven scientific articles - was approached with this method, revealing, then, that phenomenography is still infrequently used in researches in the field of organisational studies in the context of Brazil.

For Marton (1994), however, phenomenography is often used as a research method and, in some cases, as a methodology. In this essay, we conceive phenomenography as a research method with a potential contribution to the field of management education. Its analysis focus "on the way (or the different ways) in which we experience - or are aware of - the world that surrounds us" (Marton, 1994, p. 7).

This essay, concerning a methodological approach, aims to describe, elucidate and/or deepen the steps of applying a method taking into account the possibility of collaborating on the theory and practice from the experiences lived by the authors, in order to contribute to the dissemination of the method in the field of applied social sciences (Soares \& Godoi, 2017; Faria-Schützer et al., 2021).

Phenomenography as a research method may become popular in the field of management education in Brazil. We justify this possibility based on an argument by Pheralli (2011) that the student learning process is not merely cognitive. For this reason, education research should also consider the context in which learning occurs. Understanding how students perceive and experience the learning process can help professors disseminate a more suitable teaching and learning approach, revealing the potential of phenomenography's contribution (Postareff, Lindblom-Ylänne \& Nevgi, 2008) to improving management education.

This methodological essay, thus, characterises phenomenography as a research method to broaden the understanding of the phenomenon of management education in Brazil. The following sections present the 

historical evolution of phenomenography, its
epistemological and methodological principles, the constitutive assumptions, the research process, and its potential dissemination in the field of management education in Brazil.

\section{HISTORICAL EVOLUTION OF PHENOMENOGRAPHY}

Phenomenography is a research method developed in the 1970s at the University of Gothenburg, Sweden, by a group of four researchers - Ference Marton, Roger Säljö, Lars-Öwe Dahlgren, and Lennart Svensson - who sought to understand the reason why some students perform better than others and the meanings of this phenomenon. Faced with this issue, the group decided to understand the students' learning experience through action, in a reading situation, rather than through learning outcomes (Cousin, 2009; Pherali, 2011).

To this end, the researchers asked the students, in individual sessions, to read an excerpt from a book; after reading the excerpt, the students were interviewed and asked to describe their reading experience and the content addressed. The study's results revealed different conceptions of comprehending the text. The way students experienced the situation, in a different and limited perspective, was associated with the two levels of learning, one linked to the surface, and the other associated with deep learning (Pherali, 2011), which were termed first-order perspective (surface) and second-order perspective (deep).

When learning occurs at the most surface level of the process, the student does not spend much time reflecting, they are encouraged to memorise rather than understand, receive questions and activities in a more structured way, and participate in the learning processes focusing on outcomes. At the deepest level, however, learning is described as a result of pleasure from participating in the process, combined with self-direction and independence in the learning situation (Han \& Ellis, 2019).

Feldon and Tofel-Grehl (2018) explain that the way people experience a situation may be limited for they share their worldviews with one another. Therefore, from this perspective, the method of relational or non-dualist ontology and interpretive epistemology emerges, which advocates for experience as a starting point, rather than the world as such (Marton, 1981).

In 1979, Ferrence Marton coined the term phenomenography, meaning appearance and description (Cousin, 2009; Pherali, 2011), which several years later became to what is known as variation theory (Åkerlind, 2008; Pherali, 2011). Phenomenography involves describing things as they appear to the subjects, what is perceived by the senses and can be represented or written; in other words, the description of an experience that may not be entirely explicit, but it exists because it is perceived by those having the experience (Åkerlind, 2004; Feldon \& Tofel-Grehl, 2018; Marton, 1981; Sandberg, 2000; Wood, 2000).

\section{EPISTEMOLOGICAL POSITIONING}

\section{PHENOMENOGRAPHY}

Phenomenography assumes a non-dualistic ontology in which subject and phenomenon are integrated, and an epistemology that presumes knowledge construction based on a socio-constructivist-interpretative approach, that uses descriptions of experiences or conceptions to explore the nature of knowledge (Han \& Ellis, 2019; Pherali, 2011). This method goes beyond merely revealing the meanings of a phenomenon by comprehending its variability (Feldon \& Tofel-Grehl, 2018). These variations are called conceptions, which are organised according to the subject's level of understanding (Kember \& Kwan, 2000).

For phenomenography, ontology is linked not to theses philosophies but to a tradition of empirical research. This approach does not take a position in the metaphysical field's debate between materialism and idealism, as regardless of the researcher's position. It is still possible to carry out, throught it, phenomenographic research (Svensson, 1997) for the reason that conceptions are statements about phenomena rather than about subjects (Feldon \& Tofel-Grehl, 2018).

According to Pheralli (2011), phenomenography has developed a subjective and relative view of knowledge, which is opposed to the positivist view centred on the argument that there is an absolute identity for the understanding of knowledge.

Phenomenography is positioned as a second-order method. This definition does not imply dismissing first-order methodologies (subject and reality are studied separately) or heightening the controversy regarding whether access to reality occurs directly or indirectly. There is, therefore, no intention of engaging in a metaphysical debate between the real and the apparent but, rather, of understanding experiences and accessing them through the eyes of those who experienced them. As a research outcome, the method is interested in describing how phenomena are experienced in the world (Marton, 1981).

In the learning processes from which phenomenography originated, Marton (1981) explains that first-order perspectives understand that it is necessary to combine the content of the discipline and the learning process that takes place between the student, professor, and environment, resulting in the content being shared to "empty spaces in the students' heads" (Marton, 1981, p. 182). As a second-order perspective, which aims at understanding the experience of the learning process, phenomenography attempts to understand the conceptions that might result from the learning process through the variation in how students understood a concept explained by their professor (Marton, 1981; Shenton \& Hayter, 2006).

Phenomenography as a research method is interested in identifying the differences in how people understand the experience of a particular phenomenon (Cousin, 2009; Han \& Ellis, 2019), and its object of study is revealed by a qualitative analysis describing different ways of experiencing the same phenomenon, i.e., perceiving how a specific group describes a phenomenon based on their 
experiences and how this variability can help categorise and describe experience (Pherali, 2011). Phenomenography seeks to describe, analyse, and understand experiences (Marton, 1981).

There are three lines of research in phenomenography: a) the first investigates different conceptions of understanding learning and how it is linked to different student perceptions; b) the second associates the research with specific content; and c) the third, and least known, is understood as a "pure" phenomenographic investigation that focuses on people's conceptions and their realities, revolving around their daily lives (Ireland, Neofa \& Harding, 2009; Khan, 2014; Marton, 1981).

Khan (2014) exemplifies this last line of research through studies that have questioned people's conceptions of their political or economic views. Phenomenography is, thus, a method that emerged in education and was developed to improve the quality of teaching and learning processes, but would also encompass other phenomena within our reality (Ireland et al., 2009; Khan, 2014; Marton, 1981), as indicated by the results in Santos et al. (2018).

In short, phenomenography characteristics are: (a) it rejects the dualistic approach in which there is a separation between the subject and the phenomenon; (b) it has traditionally been part of the qualitative approach but can be used for generalisation (Feldon; Tofel-Grehl, 2018); (c) it investigates a related phenomenon under study (first-order indicates a researcher describing a phenomenon) from the point of view of those involved in the investigation (secondorder considers the individual's perception of the study); (d) it involves the different variations of a phenomenon and; (e) it attempts to identify the diversity of experiences and categorise them hierarchically, on a continuum, highlighting a certain pattern among the conceptions (Çekmez, Yildiz \& Bütüner, 2012), resulting in a collective network regarding the phenomenon (Cherman \& Rocha-Pinto, 2016). In the next section, we discuss the basic elements of phenomenography.

\section{BASIC ELEMENTS OF PHENOMENOGRAPHY}

Phenomenography is a research method that seeks to reveal 'how' phenomena are viewed, sensed, and perceived, based on the context in which they occur. It assumes that knowledge is essentially a question of meaning linked to a social and cultural context, which encompasses a more subjective and relative view of events (Svensson, 1997).

Phenomenography also aids in the description of similarities and differences between conceptions of, e.g., how a single situation is experienced, involving the reference and structure of the studied phenomena. As an outcome, this research method illustrates the phenomenona through the way a person describes it, and its meanings have no relation to the psychological aspects of the person as a human being or how they behave in society (Marton, 1994).

Svensson (1997) describes phenomenography as a "research programme", given the breadth of the studies carried out by Ference Marton. Marton identifies different research objectives in the field of teaching and learning, which are not only limited to describing students' experiences. Studies can also make use of the phenomenographic research programme to describe conceptions of learning, since they are particularly fundamental in the field of teaching. For this author, phenomenography is a research orientation.

The most significant characteristics of this research method involve the identification of categories of description in the outcome space and the initially explorative presentation of the data, which later came to have an analytical character (Svensson, 1997). Although phenomenography is no longer new, when it was first conceived in the 1970s, the data collection and analysis process - given the exploratory and interpretive nature of phenomenographic research - brought changes to the prevailing methodological tradition (the quantitative) and were inspired by the tradition of hermeneutical, ethnographic, and phenomenological methodologies.

For phenomenography, any situation can be experienced in a limited number of qualitatively different ways, called conceptions (Marton, 1994), to locate and systematise ways of interpreting reality based on an experience, which can be modified depending on the historical context of the moment (Marton, 1994). According to Ireland et al. (2009, p. 9), "a conception is the object of focus in any phenomenographic study. It is the relationship constituted between the subject and the phenomenon experienced. It is an intangible entity which encapsulates the way in which the subject has experienced the phenomenon".

A conception refers to the process of forming an idea or mental image through a combination of different aspects that depend on human activity, the world and the external reality. In phenomenography, a conception is thus relational to knowledge. However, it is important to emphasise that although this approach explores ideas and beliefs through descriptions of conceptions, it does not offer a philosophical study of the nature of knowledge or reality, nor a psychological study of mental processes, but rather reveals the variations in different phenomena through the object of study (Pherali, 2011).

It is therefore necessary to identify the nature of the object of study, that is, the nature of the conceptions that are linked to the nature of knowledge and thinking, and to the time (chronos) in which they were generated. Conceptions, therefore, have a relational nature, as they depend on human activity and the reality external to the individual. Likewise, knowledge is also relational, since it is created through thinking about the external reality (Svensson, 1997).

The phenomenographic researcher thus attempts to abstract, reduce, and condense the outcomes into categories of description as an effort to present content that is as close as possible to the description of the experienced phenomenon, revolving around its central characteristics (Cherman \& Rocha-Pinto, 2016). 
Categories of description are heuristic devices that help the researcher improve their understanding of the phenomenon (Cousin, 2009). They support the establishment of links between the subjects involved in the situation, and demonstrate that there are other conceptions in question to deepen the experiences of the phenomenon throughout the process (Cherman \& Rocha-Pinto, 2016; Kember \& Kwan, 2000).

The most significant elements underpinning phenomenography as a research method are thus: (a) knowledge is relational and holistic in nature; (b) conceptions are the central form of knowledge; (c) descriptions are fundamental to scientific knowledge about conceptions; (d) conceptions are based on the exploration of meanings of delimited objects; (e) the outcome space emerges through the differentiation, abstraction, reduction, and comparison of the collected data (Svensson, 1997).

The phenomenographic research unit encompasses how a phenomenon is experienced (Light \& Calkins, 2015; Sandberg, 2000), and this positioning has certain methodological implications both for data collection and for its understanding and analysis (Renström, Andersson \& Marton, 1990), which is discussed in the next section. In an effort to gather the elements that characterise phenomenography, Table 01 assembles some key aspects that characterise phenomenography.

\section{Table 1}

Characterisation of phenomenography

\begin{tabular}{|c|c|c|}
\hline Elements & Meanings & Authors \\
\hline What? & $\begin{array}{l}\text { Qualitatively describe } \\
\text { different ways of } \\
\text { experiencing a single } \\
\text { phenomenon. }\end{array}$ & $\begin{array}{l}\text { Pheralli (2011); Light } \\
\text { and Calkins (2015) }\end{array}$ \\
\hline Why? & $\begin{array}{l}\text { Identify different ways } \\
\text { in which people } \\
\text { understand } \\
\text { experience of a } \\
\text { particular } \\
\text { phenomenon. }\end{array}$ & $\begin{array}{l}\text { Cousin (2009); Feldon } \\
\text { and Tofel-Grehl (2018); } \\
\text { Han and Ellis, 2019. }\end{array}$ \\
\hline Objective & $\begin{array}{l}\text { Describe, analyse, } \\
\text { and understand the } \\
\text { subjects' experiences. }\end{array}$ & Marton (1981) \\
\hline $\begin{array}{l}\text { Research } \\
\text { Unit }\end{array}$ & Experience. & $\begin{array}{l}\text { Sandberg (2000); Light } \\
\text { and Calkins (2015) }\end{array}$ \\
\hline Where? & $\begin{array}{l}\text { Teaching-learning } \\
\text { environment. }\end{array}$ & $\begin{array}{l}\text { Marton (1981); Cousin } \\
\text { (2009); Zhao, } \\
\text { Mcconnell and Jiang } \\
\text { (2009); Pherali (2011); } \\
\text { Çekmez, Yildiz and } \\
\text { Bütüner (2012); } \\
\text { Akerlind, Mckenzie and } \\
\text { Lupton (2014); Light \& } \\
\text { Calkins (2015) }\end{array}$ \\
\hline Who? & $\begin{array}{l}\text { Agents involved in the } \\
\text { teaching and learning } \\
\text { process. }\end{array}$ & Akerlind (2008) \\
\hline How? & $\begin{array}{l}\text { Through a variety of } \\
\text { experiences and a } \\
\text { hierarchical } \\
\text { categorisation, based } \\
\text { on a certain pattern } \\
\text { between conceptions. }\end{array}$ & $\begin{array}{l}\text { Çekmez, Yildiz and } \\
\text { Bütüner (2012); Light \& } \\
\text { Calkins } \\
\text { Cherman \& } \\
\text { Pinto (2015); } \\
\text { Pocha- } \\
\text { Pinto et al. (2019) }\end{array}$ \\
\hline
\end{tabular}

Source: Elaborated by the authors.
The aspects involving 'where' and 'who' were directed towards examining the field of education in an illustrative way and can be adjusted to different contexts. Next, we present the phenomenographic research process.

\section{THE PHENOMENOGRAPHIC RESEARCH PROCESS}

Although no specific tools or methods are used in the methodological approach, phenomenography follows a specific path (Feldon \& Tofel-Grehl, 2018). To assist researchers interested in developing studies underpinned by phenomenography, we recommend a phenomenographic research process, based on readings of classical and current authors, which can be experienced through the following phases and steps in Figure 1:

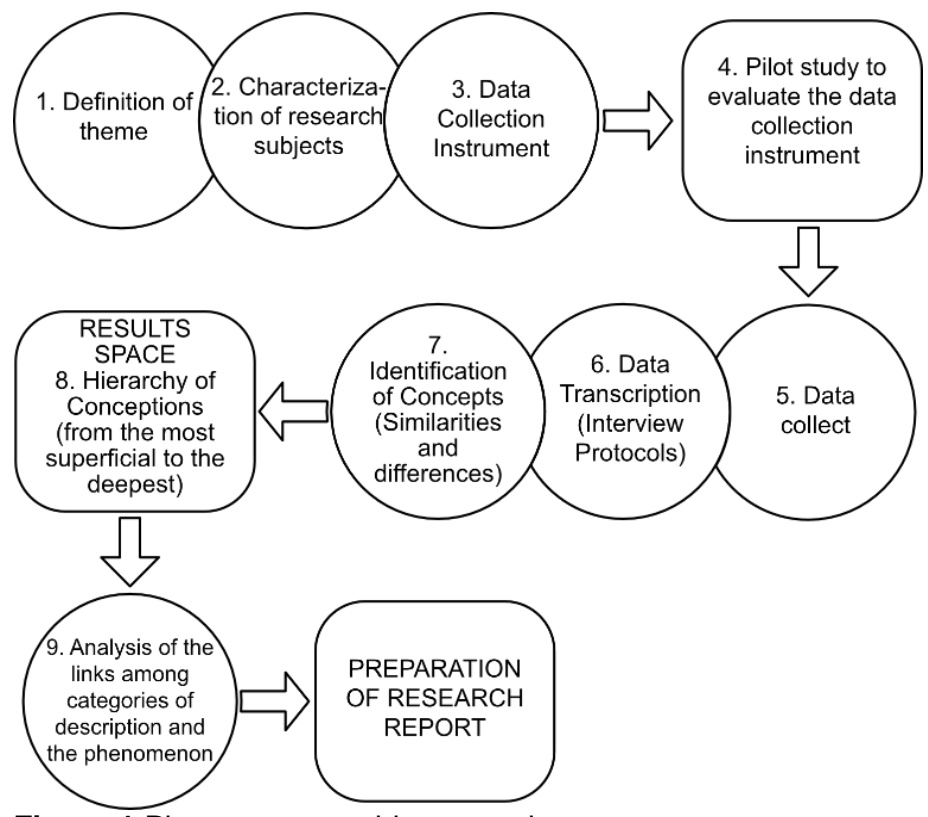

Figure 1.Phenomenographic research process

Source: Elaborated by the authors based on Feldon \& Tofel-Grehl (2018).

The first three steps of the phenomenographic research process characterize the research planning phase, and involves the delimitation of the phenomenon to be studied, the characterization of the research subjects and the data collection instruments, which may involve conducting interviews, a discussion group or drawings. The result of this step enables the structure of the data collection instrument, which may provide the subjects' reflection to capture the concept of the phenomenon.

The second phase of the process involves the operationalization of the research, which encompasses carrying out a pilot study to observe the clarity of the questions and promote adjustments based on the feedback from those involved; and data collection, which aims at establishing a dialogue that encourages the researched to talk about their conceptions (ask for examples, storytelling, reflections on the experience).

The data analysis phase of the research involves data transcription, the analysis of research protocols to identify the conceptions of the experience, through similarities and differences in meanings, which enables the 
elaboration of a reference structure with the conceptions from an initial mapping.

Along with the effort to develop this initial mapping, it is the understanding of the concepts and relationships among them, which will result in a hierarchy. This is a complex process, which requires readings and re-readings of the conceptions, in order to present, in the results space, the reflection of the limits between one conception and another with their links.

The steps allowed the researcher to delimit the space of results, characterized by the identification of categories of description, in a hierarchical manner (from the most superficial to deepest conception). After this step, the links between the categories of description and the phenomenon are analyzed in a logical and cautious manner. The last phase involves the elaboration of the research report. Feldon and Tofel-Grehl (2018) recommend the inclusion of excerpts from the research protocols to help readers judge the plausibility of their analyses, as well as to establish an articulation among the categories of description, the conceptions and the theoretical basis that can foster the results.

To illustrate the dynamic nature of the research process, we now present several studies that used phenomenography as a research method.

Emphasising the phenomenographic research process, Renstrom, Andersson and Marton (1990) and Pherali (2011) explain how they studied the learning of chemistry and geography students, respectively. They initially selected students who already had academic experience in the discipline, i.e., they had already discussed the content in classroom. The authors then prepared material related to chemistry or geography and asked the students to answer some questions. After engaging with the material, students were individually interviewed about the experience. The data collection process in phenomenographic research may occur through individual or group interviews and/or observations, as in Sandberg (2000) and Akerlind (2004). Questionnaires are not recommended (Shenton \& Hayter, 2006), although Khan (2014) argues that open-ended questionnaires can be used.

While the individual interview is the most commonly observed data collection strategy in phenomenographic research, Marton (1994) believes that data collection can also be carried out with group interviews. We also recommend the use of discussion groups (DG), following the guidelines of Godoi (2015); the use of drawings, as noted in Pherali (2011), as well as observation, using behavioural understanding and document analysis, as occurred in Amaro and Brunstein (2014) and Khan (2014).

In the phenomenographic study by Zhao, Mcconnell, and Jiang, (2009), the interview took place in three stages: the first one discussed the life history of Chinese professors interviewed (a total of 24), including their teaching careers. The interviewees were then encouraged to speak about their current career, involving beliefs, values, and experiences, with the help of a technique that the authors called "stimulated recall", which involves asking for examples and examining the experience of a critical moment. Finally, the professors were asked about their future prospects as professors working in higher education e-learning in China.

Santos and Silva (2019) propose a research script by making use of the trilogy of phenomenography - perception, thought and action, to study the conceptions of being a professor. The authors' proposal is presented in Table 2 below.

\section{Table 2}

Trilogy of phenomenography in the script

\begin{tabular}{lll}
\hline Trilogy & Meanings & Script \\
\hline Perception & $\begin{array}{l}\text { Seizes } \\
\text { (What?) }\end{array}$ & What is it to be a professor? \\
Thought & $\begin{array}{l}\text { Meaning } \\
\text { (How?) }\end{array}$ & How did you learn to be a professor? \\
Action & $\begin{array}{l}\text { Behaviour } \\
\text { (Why?) }\end{array}$ & $\begin{array}{l}\text { Tell us about your teaching } \\
\text { experiences. } \\
\text { Which were the most significant? } \\
\text { Why? }\end{array}$ \\
\hline
\end{tabular}

Source: Santos \& Silva (2019, p. 12).

The authors' proposal can work as a reference for phenomenographic studies carried out in other contexts and with other subjects, due to the potential to identify the conception of a phenomenon.

With regard to the number of study participants, Khan (2014) indicates that 15 to 20 participants are an appropriate number of research subjects. He also advises that they should be people with different characteristics in terms of gender, social position, experiences, and so on. In Light and Calkins (2015), interviews were conducted with 46 professors, divided into different career periods and disciplines.

The analysis process begins with the literal transcription of the interviews, with the objective of revealing qualitatively different conceptions (Cousin, 2009) in a limited number of categories (Khan, 2014). In his study, Khan (2014) analysed the interview protocols, which resulted in descriptions of the experience, i.e., the conceptions. This result was achieved by identifying similarities and differences between conceptions (Feldon \& Tofel-Grehl, 2018).

These conceptions, or different ways of experiencing something, emerge through the initial mapping of the phenomenon under study and the identification of the categories of description (Cherman \& Rocha-Pinto, 2016). Identifying the categories that help describe the phenomenon is the most important step of this method (Çekmez, Yildiz \& Bütüner, 2012). After identification, the categories are labelled with names that summarise and circumscribe their essence (Khan, 2014).

Next, the categories are hierarchically arranged, i.e., beginning with the surface and proceeding to the deepest level, and they are gathered in the outcome space (Cousin, 2009; Pherali, 2011). These categories should be related to the phenomenon, have a logical relationship, and be parsimonious (Cousin, 2009; Pherali, 2011). The outcome 
space delimits the variations in conceptions of the phenomenon, i.e., it reveals the different ways in which people experienced the phenomenon (Ireland et al., 2009), and can be illustrated using tables that complete the phenomenographic study (Khan, 2014). Phenomenographers are interested in understanding how people's perceptions and experiences are dynamically delimited by the behaviour of others and institutions (Cousin, 2009). The entire process should result in an analytical text that systematises the results.

Seeking to provide more reliability, a topic that will be discussed in the next paragraphs, excerpts from interview protocols with the research subjects' experiences should be included, for as it is stated by Cousin (2009), such action helps readers assess the plausibility of the analysis.

For Akerlind (2008), phenomenographic research focused on improving teaching can be carried out in two stages: first, with phenomenographic interviews, to emphasise the variations in the teaching and learning situation through employing a student-centred conception; and second, by using these variations in teaching situations, allowing the students to experience new moments, and by using reflection to distinguish their conception and the others identified.

This process of reflection, Akerlind (2008) explains, can be developed through contrasts (obtaining differences between the highlighted descriptions), generalisation (highlighting a pattern in the experience), separation (separating descriptions of a phenomenon), and fusion (fusing all the essential characteristics of the phenomenon). The author warns that to improve the development of phenomenographic studies, it is necessary to understand the epistemological assumptions of the subjects' conception of teaching to better ground the findings (Åkerlind, 2008).

Since phenomenography is a research method with some peculiarities, particularly in terms of the data analysis process, the path taken when carrying out phenomenographic research should be described in detail, and the researcher should take care to explain and clarify that the results of a phenomenographic study are located within the outcome space of conceptions (Åkerlind, 2008).

\subsection{Validity, reliability, and generalisation}

Pherali (2011) advises that the researcher should try to put their beliefs aside so that they do not come to, somehow, modify interpretations of the conceptions, since they are fundamental to the study. However, the author recognises that such distancing can be a difficult process to deal with. Despite the fact that phenomenographic research is guided by the qualitative approach, it incorporates in practice deductive elements that are more common in quantitative approach. While data analysis process in qualitative research is essentially inductive. Merriam (2009) notes that there may be a mild process of deduction when the categories of analysis are discovered, verified, tested, and confirmed.
Although it may be controversial and not concretely defined, reliability in phenomenographic research can be ensured by describing a complete and clear process, including participants' characteristics, the process of collecting and delimiting the categories - underpinned by the data and the literature (Çekmez, Yildiz \& Bütüner, 2012) - as well as verification from other researchers in the category identification process (Dadkhah, Lagzian \& Santoro, 2019; Khan, 2014) by allowing additional researchers to analyse the data and find at least $90 \%$ of the same categories already identified; there may also be mutual dialogue between researchers to improve the process of reflection with regard to the categories defined from data analysis. In Cousin (2009), interviews were analysed by two researchers in the area in order to demonstrate the consistency of interpretations between the transcriptions and the categories. Cousin (2009) clarifies that another way to ensure reliability is to present descriptions of the categories supported by excerpts from the interviews.

Validity can be achieved to the extent that the data in question can be replicated to understand the same phenomenon in another context (Khan, 2014). This validity can be classified as communicative (the researcher's ability to convince the scientific community through seminars or conferences) or pragmatic (how useful the results are for the target audience).

Research makes a practical contribution when the study results enable an interpretation of the nature of human experiences and provide support for the development of improvements to teaching (Åkerlind, 2008). The practical meaning of this research method is therefore related to changes in conceptions of teaching, impacts on the professors' teaching approaches, comprehension of the students' learning practices, and the professional development of professors at higher education institutions. Finally, the practical implications of this strategy can contribute to those developing curricula and those involved in the educational planning process (Khan, 2014).

\section{POTENTIAL USES OF PHENOMENOGRAPHY IN MANAGEMENT EDUCATION}

Phenomenography, as a research method (Sandberg, 2000), has been used both in the academic environment and professional practice aiming to identify the various conceptions of social actors involved in learning and management processes. This research method helps researchers elucidate relevant research questions in relation to learning, both in the academic (Santos \& Silva, 2019) and work environment (Jardim \& Rocha-pinto, 2017; Broman, Ruas \& Rocha-pinto, 2019; Amaro, 2020).

Regarding the organizational field, the bibliographical review carried out by Santos et al. (2018) stands out. These researchers identified 11 articles published in events and journals until 2016, being one of them methodological in nature, and the others involving studies related to topics 
such as professional entrepreneurial skills, role of coaching in individual learning, critical factors for the implementation of a balanced scorecard, innovation and investments in the electricity sector and valuation of knowledge in organizations.

From 2017 to 2020, 09 articles that used the phenomenographic method, according to a query in the Spell repository held on October 30, 2021, were published. Two articles published in 2017, 02 in 2018, 02 in 2019, and 03 in 2020 were identified. From the articles published in the period 2017-2020, three of them address methodological aspects, such as the quality of the method (Trevia, Broman, Rocha-pinto \& Guimarães, 2018), reflection on the knowledge generated by the adoption of phenomenography (Inglat \& Villardi, 2018), and and the proposition of a theoretical-methodological approach to the practice of corporate governance (Trevia, Jardim \& Rocha Pinto, 2020). Other studies also addressed, in their researches, skills in production scheduling routines (Jardim e Rochapinto, 2017), the construction of collective competencies (Broman, Ruas \& Rocha-pinto, 2019), and conceptions of work and development of professional skills (Amaro, 2020). At last, two more specific studies involving forensic accounting and accounting expertsise (Imoniana \& Aquino, 2017) and "accountability" in organizational routines and internal controls (Vida \& Rocha-pinto, 2020) used Phenomenography as a methodological trail.

The only article identified that involved the context of education in management was the one written by Santos e Silva (2019). The results of the study carried out with professors who work in undergraduate and graduate courses revealed the various conceptions that involve teaching practice. Santos and Silva (2019) concluded that the formation of these conceptions is linked to knowledge that was influenced by personal, professional and institutional factors and by the dominant ideologies in the field. The deepest conceptions involve principles and values built from socio-emotional relationships between professorstudent and characterize a transformation in the perspectives of meaning concerning being a teacher, when compared with more superficial perspectives.

These results reveal that an increasing number of studies using phenomenology in the organizational context have been conducted in Brazil. However, considering the fact that only one research, related to the conceptions of being a professor, was found published in a journal, it is concluded that the use of this method in management education is still scarce in Brazil.

Management education is a field of research and practice that involves various social actors, whether they are students, professors or educational managers, who have experiences in cultural, historical, political and social contexts with the purpose of enhancing learning.

Pherali (2011) concludes that phenomenography is a suitable methodology for investigating university students' conceptions, since phenomenography seeks to discover the different ways in which people experience and, therefore, conceptualize the range of phenomena in the perceived world. Its implications for teaching encourage those interested in the process to reflect upon it. By understanding how students conceptualise certain subjects or topics and the fact that this conceptualisation occurs in a variety of ways, those who think about teaching can promote improvements to the educational process, which is the main contribution of phenomenography (Renström, Andersson \& Marton, 1990; Samuelowicz \& Bain, 2001).

The results of phenomenological research on teaching initially reveal, through the outcome space, a realistic view of what the chosen phenomenon is able to develop in students when it is being experienced. It is possible to observe whether the topic of the class aids in the process of reflection, thereby transforming learners' worldview (Postareff, Lindblom-Ylänne \& Nevgi, 2008; Renström, Andersson \& Marton, 1990).

We can also evaluate the coherence of books and educational resources by engaging the conceptions revealed in the study, and, as a result, enable the improvement of theories, schemas, and orders of topics presented by understanding that the way information is presented may hinder or impede student's learning in the first conception of the study, the surface of the results (Postareff, Lindblom-Ylänne \& Nevgi, 2008).

By comprehending students' perceptions, phenomenography offers professors support for developing a better understanding of students' learning processes, ranging from the simplest and most essential level of understanding to the deepest one of the same topic (Renström, Andersson \& Marton, 1990). Professors can also perceive how their values, beliefs, and behaviours affect the learning process, which can result in benefits or harms. Therefore, as phenomenography stimulates the reflection process, it also drives transformative potential (Postareff, Lindblom-Ylänne \& Nevgi, 2008; Samuelowicz \& Bain, 2001).

Pherali (2011) explains that the contributions and popularity of phenomenography in learning processes are evident, particularly in higher education, as the data reveal meanings of a phenomenon that are easily understood and accessible to non-subject specialists. The contribution is therefore associated with the phenomenon being investigated through the "user" construct, rather than through the observer's gaze (Shenton \& Hayter, 2006). This approach helps promote teaching capable of perceiving the existence of variations in the same phenomenon, allowing learners to observe the phenomenon in different ways and, finally, to learn it.

Even though several international authors highlight the relevance of using Phenomenography in the context of educational training, it was found that in the context of management education in Brazil, the use of this method in this context is still not widespread.

Understanding the conceptions of students and professors using phenomenography can broaden the understanding of teaching and learning processes. To 
contribute to the dissemination of studies in the field of management education, we suggest some themes that can be analyzed using this research strategy, such as the perception of undergraduate and graduate students on the conceptions of the learning environment, the relationship professor-student, teaching strategies disseminated by professors in the experience of learning in a meaningful and transformative way. Conceptions of student engagement, self-directed learning, motivation for learning and ways of learning are research topics that can be analyzed using Phenomenography.

The implications of the types of students' experiences in the learning space - both formal and informal - can help explain the skill development process as well as the dynamics of the experiential process in learning.

The role of the reflective process in learning can also be analysed using phenomenography, which can reveal different conceptions of how students reflect and can help identify teaching strategies that can strengthen students' capacity for reflection, contributing to the development of a more critical and reflective professional.

Topics such as ethical and responsible behaviour in teaching and research, professor and researcher training, academic learning and training, teaching action and learning environment, education for sustainability, professor identity and professionalism and educational managers' skills, linked to the Division of Education and Research in Administration and Accounting at the Brazilian Academy of Management (Associação Nacional de Pós-Graduação e Pesquisa em Administração - ANPAD), for example, indicate that phenomenography presents opportunities for development in the area of management education in Brazil.

\section{FINAL REFLECTIONS}

We presented phenomenography in this essay as a research method, seeking not only to define some of its history, but also to describe its epistemological assumptions, its basic elements, and the methodological path, so that researchers could understand the procedures and steps necessary to effectively carry out a study. We also indicated several potential uses in management education.

By questioning ourselves the reason why we understand and interpret same events in different ways, even though we live in the same world and environment, at same time as going after researches to answer it, we could see that studies that use phenomenography seek to empirically emphasise the different ways in which people experience, perceive, learn, understand, and conceptualise the range of phenomena that occurs in the world (Çekmez, Yildiz \& Bütüner, 2012). By dynamically analysing the variation in a phenomenon, we can make theoretical, empirical, and practical contributions to the field of learning.

Therefore, in order to contribute to the reflection on the role of phenomenography in studies in the area of management education in the context of Brazil, we resent in the following paragraphs some of the contributions and limitations related to this research method as a starting point for researchers, interested in adopting phenomenography in their studies, to reflect on its implications.

As for the contributions of this method, phenomenography focuses on the conception of teaching or a student-centred understanding; it describes a learning situation with implications for both professors and students (Åkerlind, 2008; Çekmez, Yildiz \& Bütüner, 2012); it also helps explain how certain teaching strategies can contribute to comprehending students' difficulties regarding the understanding (Åkerlind, Mckenzie \& Lupton, 2014); furthermore, it strengthens the professor's awareness of variations in conceptions of a specific phenomenon, which can prevent misunderstandings, thereby reconfiguring the teaching-learning process (Çekmez, Yildiz \& Bütüner, 2012); and it helps predict what might come to encourage students to perceive details in the learning process (Åkerlind, Mckenzie \& Lupton, 2014).

In addition to all that, phenomenography also contributes to a better curriculum design (Çekmez, Yildiz \& Bütüner, 2012); it provides categories of description for the phenomenon studied and, through the awareness process or reflective dialogues, it helps the subjects involved in an experience achieve a deeper understanding of situations related to learning, the work environment, or life (Marton, 1981; Renström, Andersson \& Marton, 1990); and it reveals that there are other conceptions of the phenomenon in question to deepen experiences in the process and provide support for the professor to better develop students' comprehension in the learning process, ranging from the simplest and most essential conception to the most in-depth conception of the same topic (Postareff, Lindblom-Ylänne \& Nevgi, 2008; Renström, Andersson \& Marton, 1990; Samuelowicz \& Bain, 2001).

Phenomenography, similar to any research method, has also its limitations. One involves the subject's experiences, whether they are professional, social, or part of formal education, which differ for each person and influence their perception (Çekmez, Yildiz \& Bütüner, 2012). And the other involves the researchers' experiences, as their history can influence the research process. One way to minimise such interference is to explicitly reveal researchers' life stories along with their histories and experiences. We can also consider the category definition process to be another limitation. Thus, to reduce this final limitation, it is advisable that the collection and analysis process be conducted by more than one researcher (Çekmez, Yildiz \& Bütüner, 2012).

With that being said, as phenomenography is still not a very popular research method, there is a need to explain that the outcome space is the study's result (Åkerlind, 2008). The researcher is also required to carry out an exhaustive process of reflection in pursuit of the conceptions that will be categorised (Pherali, 2011), and a lack of experience with using phenomenography may limit the process of reflection.

Our expectation is that this methodological essay will contribute to encouraging the dissemination of 
Santos \& Silva - Phenomenography as a research method for Management education

phenomenography in brazilian studies involving topics related to management education, with an emphasis on the experience of students and professors in the environment and in learning processes. As with any research method or strategy, we acknowledge that the attempt to establish a framework for carrying out phenomenographic research may elicit reflections and criticism, which can contribute to advances in management education, a multidisciplinary and complex field of research.

\section{REFERENCES}

Åkerlind, G. S. (2004). A new dimension to understanding university teaching. Teaching in Higher Education, 9(3), 363-375. https://doi.org/10.1080/1356251042000216679

Åkerlind, G. S. (2008). A phenomenographic approach to developing academics' understanding of the nature of teaching and learning. Teaching in Higher Education, 13(6), 633-644. https://doi.org/10.1080/13562510802452350

Åkerlind, G., Mckenzie, J., \& Lupton, M. (2014). The potential of combining phenomenography, variation theory and threshold concepts to inform curriculum design in higher education. In J. Huisman \& M. Tight (Eds.), Theory and Method in Higher Education Research II. International Perspectives on Higher Education Research, 10. UK: Emerald Group Publishing Limited. https://doi.org/10.1108/s1479-3628(2014)0000010017

Amaro, R. A. (2020). Concepções de trabalho e desenvolvimento da competência profissional: Estudo fenomenográfico com agentes locais de inovação do Sebrae. Organizações \& Sociedade, 27(92), 15-34. https://doi.org/10.1590/1984$\underline{9270921}$

Amaro, R. D. A., \& Brunstein, J. (2014). As contribuições da fenomenografia para os estudos da competência profissional. Revista Alcance, 21(4), 585-611. https://doi.org/10.14210/alcance.v21n4.p585-611

Broman, S. L. S., Ruas, R. L., \& Rocha-Pinto, S. R. (2019). A construção de competências coletivas na dinâmica das rotinas orçamentárias. Cadernos EBAPE.BR, 17, 871-885. https://doi.org/10.1590/1679-395174729

Burrell, G., \& Morgan, G. (2017) Sociological paradigms and organizational analysis: Elements of the sociology of corporate life. New York: Routledge. https://doi.org/10.4324/9781315609751

Çekmez, E., Yildiz, C., \& Bütüner, S. Ö. (2012). Phenomenographic research method. Electronic Journal of Science and Mathematics Education, 6(2), 77-102.

Cherman, A., \& Rocha-Pinto, S. R. da (2016). Valoração do conhecimento nas organizações e sua incorporação nas práticas e rotinas organizacionais. Revista Brasileira de Gestão de Negócios, 18(61), 416-435. https://doi.org/10.17771/pucrio.acad.23561

Cousin, G. (2009). Researching learning in higher education: An introduction to contemporary methods and approaches. New York: Routledge. https://doi.org/10.4324/9780203884584

Dadkhah, M., Lagzian, M., \& Santoro, G. (2019). How can health professionals contribute to the internet of things body of knowledge: a phenomenography study. Journal of Information and Knowledge Management Systems, 49(2), 229-240. https://doi.org/10.1108/vjikms-10-2018-0091

Faria-Schützer, D. B. Surita, F. G. Alves, V. L. P., Bastos, R. A., Campos, C. J. G., \& Turato, E. R. (2021) Seven steps for qualitative treatment in health research: The clinicalqualitative content analysis. Ciência \& Saúde Coletiva, 26(1), 265-274. https://doi.org/10.1590/1413$\underline{81232020261.07622019}$
Feldon, D. F., \& Tofel-Grehl, C. (2018). Phenomenography as a foundation for mixed models research. American Behavioral Scientist, 62(7), 887-899. https://doi.org/10.1177/0002764218772640

Godoi, C. K. (2015). Grupo de discussão como prática de pesquisa em estudos organizacionais. Revista de Administração de Empresas, 55(6), 632-644. https://doi.org/10.1590/s0034759020150603

Han, F., \& Ellis, R. A. (2019). Using phenomenography to tackle key challenges in science education. Frontiers in Psychology, 10, 1414 https://doi.org/10.3389/fpsyg.2019.01414

Imoniana, J. O., \& Aquino, A. A. (2017). Contabilidade forense e perícia contábil: Um estudo fenomenográfico. Revista Organizações em Contexto, 13(26), 101-126.

Inglat, L. P. S., \& Villardi, B. Q. (2018). Refletindo sobre a fenomenografia na prática de pesquisa qualitativa em organizações: Pesquisador reflexivo e reflexão pública. Revista ADM.MADE, 22(2), 62-79. https://doi.org/10.21714/2237-51392018v22n2p062079

Ireland, J. T. M., Neofa, Z., \& Harding, T. (2009). The tale of four researchers: Trials and triumphs from the phenomenographic research specialization. Proceedings of the Australian Association for Research in Education (AARE) 2008 International Research Conference. Changing Climates: Education for Sustainable Futures. The Australian Association for Research in Education. https://doi.org/10.1007/bf03219531

Jardim, L. S. S., \& Rocha-Pinto, S. R. (2017). Desvelando a competência em rotinas de programação da produção a partir do método fenomenográfico. Revista Alcance, 24(4), 602-618.

https://doi.org/10.14210/alcance.v24n4(Out/Dez).p602$\underline{618}$

Kember, D., \& Kwan, K.P. (2000). Lecturers' approaches to teaching and their relationship to conceptions of good teaching. Instructional Science, 28(5), 469-490. https://doi.org/10.1007/978-94-010-0593-7 10

Khan, S. H. (2014). Phenomenography: A qualitative research methodology in Bangladesh. International Journal on New Trends in Education and Their Implications, 5(2), 34-43.

Light, G., \& Calkins, S. (2015). The experience of academic learning: uneven conceptions of learning across research and teaching. Higher Education, 69(3), 345-359. https://doi.org/10.1007/s10734-014-9779-0

Marton, F. (1981). Phenomenography - describing conceptions of the world around us. Instructional Science, 10(2), 177-200. https://doi.org/10.1007/bf00132516

Marton, F. (1994). The idea of phenomenography. In R. Ballantyne \& C. Bruce (Eds.), Phenomenography: Philosophy and practice (pp. 7-8). Centre for Applied Environmental and Social Education Research Printed in Brisbane. Brisbane/Australia: QUT Publications and Printing.

Merriam, S. B., \& Tisdell, E. J. (2015). Qualitative research: A guide to design and implementation. San Francisco: John Wiley \& Sons.

Minayo, M. C. S., Deslandes, S. F., \& Gomes, R. (2011). Pesquisa social: Teoria, método e criatividade. Petrópolis: Vozes.

Pherali, T. (2011). Phenomenography as a research strategy: Researching environmental conceptions. Germany: Lambert Academic Publishing.

Postareff, L., Lindblom-Ylänne, S., \& Nevgi, A. (2008). A follow-up study of the effect of pedagogical training on teaching in higher education. Higher Education, 56(1), 29-43. https://doi.org/10.1007/s10734-007-9087-z

Renström, L., Andersson, B., \& Marton, F. (1990). Students' conceptions of matter. Journal of Educational Psychology, 82(3), 555. https://doi.org/10.1037/0022-0663.82.3.555 
Rocha-Pinto, S. R., Jardim, L. S., Broman, S. L. S., Guimarães, M. I. P., \& Trevia, C. F. (2019). Phenomenography's contribution to organizational studies based on a practice perspective. RAUSP Management Journal, 54, 384-398. https://doi.org/10.1108/rausp-05-2019-0085

Samuelowicz, K., \& Bain, J. D. (2001). Revisiting academics' beliefs about teaching and learning. Higher Education, 41(3), 299-325. https://doi.org/10.1023/a:1004130031247

Sandberg, J. (2000). Understanding human competence at work: An interpretative approach. Academy of Management Journal, 43(1), 9-25. https://doi.org/10.2307/1556383

Santos, L. S., Leal, F. G., Alperstedt, G. D., \& Feuerschütte, S. G. (2018). O método fenomenográfico na pesquisa científica em administração no Brasil: análise e discussão sobre seu uso. Revista de Ciências da Administração, 20(50), 129146. https://doi.org/10.5007/2175-8077.2018v20n50p129

Santos, G., \& Silva, A. (2019). "Mergulhando" nos significados e revelando concepções do ser professor na administração. Revista de Administração Mackenzie, 20(5),1-34. https://doi.org/10.1590/16786971/eRAMG190144

Silva, A.B. \& Roman, J., Neto (2010). Perspectiva multiparadigmática nos estudos organizacionais. In C. K. Godoi, R. Bandeira-de-Mello \& A. B. Silva (Orgs.), Pesquisa Qualitativa em Estudos Organizacionais: Paradigmas, Estratégias e Métodos (pp. 63-97). 2 ed. São Paulo: Saraiva.

Soares, J. R. R., \& Godoi, C. K. (2017). A metodologia da análise sociológica do discurso em estudos turísticos: O processo de transformação da imagem turística e sua relação com a lealdade. Pasos - Revista de Turismo y Patrimonio Cultural, 15(1), 245-260. https://doi.org/10.25145/i.pasos.2017.15.015

Shenton, A. K., \& Hayter, S. (2006). Terminology deconstructed: Phenomenographic approaches to investigating the term "information". Library \& Information Science Research, 28(4), 563-578. https://doi.org/10.1016/j.lisr.2006.10.003

Stake, R. E. (2016). Pesquisa qualitativa: Estudando como as coisas funcionam. Porto Alegre: Penso Editora. https://doi.org/10.18675/1981-8106.v30.n.63.s14553

Svensson, L. (1997) Theoretical foundations of phenomenography. Higher Education Research \& Development, 16(2), 159-171. https://doi.org/10.1080/0729436970160204

Trevia, C. F., Broman, S. L. S., Jardim, L. S., Rocha-Pinto, S. R., \& Guimarães, M. I. P. (2018). Qualidade em Fenomenografia nas Organizações. Revista ADM.MADE, 22(2), 48-61. https://doi.org/10.21714/223751392018v22n2p048061

Trevia, C. F., Jardim, L. S., \& Rocha-Pinto, S. R. (2020). Governança corporativa e fenomenografia: Revisão de literatura e proposição de abordagem teóricometodológica. Revista Organizações em Contexto, 16(31), 247-265.

Vidal, D. S. M., \& Rocha-Pinto, S. R. (2020). A incorporação da 'accountability' em rotinas organizacionais de controles internos. Revista Ciências Administrativas, 26, 1-15. https://doi.org/10.5020/2318-0722.2020.8095

Wood, K. (2000). The experience of learning to teach: Changing student teachers' ways of understanding teaching. Journal of Curriculum Studies, 32(1), 75-93. https://doi.org/10.1080/002202700182862

Zhao, J., Mcconnell, D., \& Jiang, Y. (jan. 2009). Teachers' conceptions of e-learning in Chinese higher education. Campus-Wide Information Systems, 26(2), 90-97. https://doi.org/10.1108/10650740910946800 


\section{CONTEXTUS}

\section{REVISTA CONTEMPORÂNEA DE ECONOMIA E GESTÃO}

CONTEXTUS

CONTEMPORARY JOURNAL OF ECONOMICS AND

MANAGEMENT.

\section{ISSN 1678-2089}

\section{ISSNe 2178-9258}

1. Economics, Administration and Accounting - Journal

2. Federal University of Ceará. Faculty of Economics,

Administration, Actuaries and Accounting

\section{FACULTY OF ECONOMICS, ADMINISTRATION, ACTUARIES} AND ACCOUNTING

University Av. - 2486, Benfica

60020-180, Fortaleza-CE

BOARD: Paulo Rogério Faustino Matos Danielle Augusto Peres

Website: www.periodicos.ufc.br/contextus

E-mail: revistacontextus@ufc.br

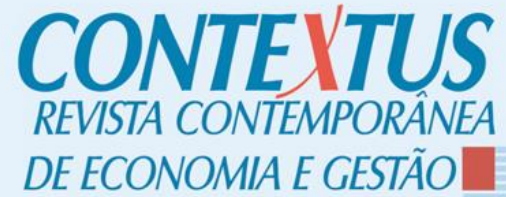

UNIVERSIDADE

FEDERAL

DO CEARÁ

FACULDADE

DE ECONOMIA,

ADMINISTRAÇÃO,

ATUÁRIA

E CONTABILIDADE

\section{Qunals}

DORA

ABEC

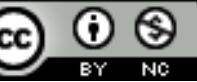

Contextus is classified in the Qualis - Capes system as a B1 journal, in the area of Public and Business Administration, Accounting and Tourism (2013-2016).

Contextus agrees and signs the San Francisco Declaration on Research Assessment (DORA).

Contextus is associated with the Brazilian Association of Scientific Editors.

This work is licensed under a Creative Commons Attribution - NonCommercial 4.0 International license.
EDITOR-IN-CHIEF

Diego de Queiroz Machado (UFC)

\section{ASSISTANT EDITORS}

Alane Siqueira Rocha (UFC)

Márcia Zabdiele Moreira (UFC)

\section{ASSOCIATE EDITORS}

Adriana Rodrigues Silva (IPSantarém, Portugal)

Alessandra de Sá Mello da Costa (PUC-Rio)

Allysson Allex Araújo (UFC)

Andrew Beheregarai Finger (UFAL)

Armindo dos Santos de Sousa Teodósio (PUC-MG)

Brunno Fernandes da Silva Gaião (UEPB)

Carlos Enrique Carrasco Gutierrez (UCB)

Dalton Chaves Vilela Júnior (UFAM)

Elionor Farah Jreige Weffort (FECAP)

Gabriel Moreira Campos (UFES)

Guilherme Jonas Costa da Silva (UFU)

Henrique César Muzzio de Paiva Barroso (UFPE)

Jorge de Souza Bispo (UFBA)

Keysa Manuela Cunha de Mascena (UNIFOR)

Manuel Anibal Silva Portugal Vasconcelos Ferreira (UNINOVE)

Marcos Cohen (PUC-Rio)

Marcos Ferreira Santos (La Sabana, Colombia)

Mariluce Paes-de-Souza (UNIR)

Minelle Enéas da Silva (La Rochelle, France)

Pedro Jácome de Moura Jr. (UFPB)

Rafael Fernandes de Mesquita (IFPI)

Rosimeire Pimentel (UFES)

Sonia Maria da Silva Gomes (UFBA)

Susana Jorge (UC, Portugal)

Thiago Henrique Moreira Goes (UFPR)

\section{EDITORIAL BOARD}

Ana Sílvia Rocha Ipiranga (UECE)

Conceição de Maria Pinheiro Barros (UFC)

Danielle Augusto Peres (UFC)

Diego de Queiroz Machado (UFC)

Editinete André da Rocha Garcia (UFC)

Emerson Luís Lemos Marinho (UFC)

Eveline Barbosa Silva Carvalho (UFC)

Fátima Regina Ney Matos (ISMT, Portugal)

Mario Henrique Ogasavara (ESPM)

Paulo Rogério Faustino Matos (UFC)

Rodrigo Bandeira-de-Mello (FGV-EAESP)

Vasco Almeida (ISMT, Portugal)

\section{SCIENTIFIC EDITORIAL BOARD}

Alexandre Reis Graeml (UTFPR)

Augusto Cezar de Aquino Cabral (UFC)

Denise Del Pra Netto Machado (FURB)

Ednilson Bernardes (Georgia Southern University, USA)

Ely Laureano Paiva (FGV-EAESP)

Eugenio Ávila Pedrozo (UFRGS)

Francisco José da Costa (UFPB)

Isak Kruglianskas (FEA-USP)

José Antônio Puppim de Oliveira (UCL)

José Carlos Barbieri (FGV-EAESP)

José Carlos Lázaro da Silva Filho (UFC)

José Célio de Andrade (UFBA)

Luciana Marques Vieira (UNISINOS)

Luciano Barin-Cruz (HEC Montréal, Canada)

Luis Carlos Di Serio (FGV-EAESP)

Marcelle Colares Oliveira (UFC)

Maria Ceci Araujo Misoczky (UFRGS)

Mônica Cavalcanti Sá Abreu (UFC)

Mozar José de Brito (UFL)

Renata Giovinazzo Spers (FEA-USP)

Sandra Maria dos Santos (UFC)

Walter Bataglia (MACKENZIE) 